\title{
Host plant recognition by the root feeding clover weevil, Sitona lepidus (Coleoptera: Curculionidae)
}

\author{
S.N. Johnson ${ }^{1 *}$, P.J. Gregory ${ }^{1}$, P.J. Murray², \\ X. Zhang ${ }^{3}$ and I.M. Young ${ }^{3}$ \\ ${ }^{1}$ School of Human and Environmental Sciences, Department of Soil \\ Science, University of Reading, Whiteknights, PO Box 233, \\ Reading, RG6 6DW, UK: ${ }^{2}$ Institute of Grassland and Environmental \\ Research, North Wyke, Okehampton, Devon EX20 2SB, UK: \\ ${ }^{3}$ Scottish Infomatics Mathematics Biology and Statistics (SIMBIOS) Centre, \\ University of Abertay Dundee, Bell Street, Dundee, D1 1HG, UK
}

\begin{abstract}
This study investigated the ability of neonatal larvae of the root-feeding weevil, Sitona lepidus Gyllenhal, to locate white clover Trifolium repens L. (Fabaceae) roots growing in soil and to distinguish them from the roots of other species of clover and a co-occurring grass species. Choice experiments used a combination of invasive techniques and the novel technique of high resolution X-ray microtomography to non-invasively track larval movement in the soil towards plant roots. Burrowing distances towards roots of different plant species were also examined. Newly hatched S. lepidus recognized T. repens roots and moved preferentially towards them when given a choice of roots of subterranean clover, Trifolium subterraneum L. (Fabaceae), strawberry clover Trifolium fragiferum L. (Fabaceae), or perennial ryegrass Lolium perenne L. (Poaceae). Larvae recognized $T$. repens roots, whether released in groups of five or singly, when released $25 \mathrm{~mm}$ (meso-scale recognition) or $60 \mathrm{~mm}$ (macro-scale recognition) away from plant roots. There was no statistically significant difference in movement rates of larvae.
\end{abstract}

\section{Introduction}

Root herbivory by soil-dwelling insects has a large and significant impact on agricultural crops leading to considerable losses in yield (Brown \& Gange, 1990; Villani \& Wright, 1990; Hunter, 2001). Despite this, most research to date has focused on above-ground insect herbivores to the comparative neglect of root herbivores. Hunter (2001) estimated that $98 \%$ of published work on insect herbivores is concerned with above-ground insect damage, partly due to

*Fax: +44 (0) 1183786660

E-mail: S.N.Johnson@reading.ac.uk the fact that edaphic processes are more demanding to analyse. Little is therefore known about how subterranean insect herbivores locate and recognize roots in the soil and whether they can distinguish host plant roots from unsuitable non-host plant roots.

A range of insect herbivores, including species of Orthoptera, Lepidoptera, Diptera, Homoptera, Coleoptera and Hymenoptera spend part of their life-cycle, usually the larval stage, in the soil feeding on roots (Brown \& Gange, 1990). Relatively few species have been studied in the context of host plant location, most notably the carrot-root fly Psila rosae (Fabricius) (Diptera: Psilidae) (Jones \& Coaker, 1979; Ryan \& Guerin, 1982; Guerin \& Ryan, 1984), and the western corn root worm Diabrotica virgifera 
virgifera, (LeConte) (Coleoptera: Chrysomelidae) (Strnad \& Dunn, 1990; Bernklau \& Bjostad, 1998a,b). The chemical ecology of soil-dwelling insects is thus poorly understood. However, an understanding of how soil insects locate roots could provide a means of controlling them, perhaps by manipulating the chemical signals that they usually exploit to locate plants. This would be comparable to methods used to control above-ground insects (Agelopoulos et al., 1999).

Weevils of the genus Sitona (Coleoptera: Curculionidae) tend to be specific feeders on legume plants (Murray \& Clements, 1994). The adult feeds above-ground on foliage, where the female weevil lays eggs that fall to the soil surface, giving rise to soil-dwelling larvae that then attack the root system. Such larvae (neonates) are $c .1 \mathrm{~mm}$ in length and feed initially on root nodules containing $\mathrm{N}_{2}$-fixing Rhizobium spp. bacteria, before moving on to progressively bigger roots during larval development (Bigger, 1930). The clover root weevil Sitona lepidus Gyllenal (Coleoptera: Curculionidae) causes considerable economic damage to grassland systems by attacking white clover Trifolium repens L. (Fabaceae) which is valued both as a high quality forage legume and for the nitrogen enrichment it provides to the system as a whole (Mowat \& Shakeel, 1989; Murray et al., 1996). Sitona lepidus is widely distributed throughout the northern hemisphere but has recently been accidentally introduced to New Zealand, where it has flourished in the absence of effective natural enemies, and continues to threaten white clover which underpins New Zealand's pastoral industries (Barratt et al., 1996; Phillips et al., 2000).

The adult stage has been extensively studied, but much less is known about the ecology of the root-feeding larval stages that live in the soil. Adult S. lepidus weevils are host specific on Trifolium spp., preferring white clover T. repens (Murray \& Clements, 1994). However, it remains unclear if the soil-dwelling larval stages can recognize and locate $T$. repens roots from a distance or whether they can distinguish T. repens from other plant roots that are either less acceptable or entirely unsuitable.

The aim of this study was to determine whether newly hatched $S$. lepidus larvae could locate $T$. repens roots and distinguish them from the roots of a co-occurring grass species and the roots of other species of clover that are morphologically similar to $T$. repens. It was hypothesized that neonatal $S$. lepidus larvae were, like the adults, host-specific to $T$. repens and could locate and recognize host plant roots and distinguish them from unsuitable plant roots. The objectives were to: (i) investigate whether neonatal S. lepidus larvae could recognize host plant roots in the soil at two distances, $25 \mathrm{~mm}$ (meso-scale recognition) and $60 \mathrm{~mm}$ (macro-scale recognition), from roots of other plant species; and (ii) determine whether neonatal S. lepidus larvae displayed different movement rates in the soil in response to roots of different species of plants. The second objective was investigated because the searching behaviour of many above-ground insect herbivores frequently involves either intensification or reduction in locomotion when locating host plants (Bell, 1990).

These experimental objectives were pursued using both invasive techniques in which larvae were destructively recovered from soil-filled tubes, and a non-invasive technique using high resolution $X$-ray microtomography. This technique permits the movement of very small soil insects (c. $1 \mathrm{~mm}$ ) like neonatal S. lepidus larvae to be tracked within the soil over time (Johnson et al., 2004).

\section{Materials and methods}

\section{Insects and plants}

A captive population of adult $S$. lepidus weevils, caught from grass/clover swards at North Wyke, Devon, UK $\left(50^{\circ} 769^{\prime} \mathrm{N}, 3^{\circ} 901^{\prime} \mathrm{W}\right)$, was maintained at $20^{\circ} \mathrm{C}, 85 \%$ humidity and 16:8 light:dark. Eggs harvested from female insects were placed on dampened filter paper inside sealed Petri dishes (diameter $90 \mathrm{~mm}$ ) and stored at $3^{\circ} \mathrm{C}$ until required, whereupon dishes were incubated at $25^{\circ} \mathrm{C}$ until larvae emerged.

A commercial cultivar of $T$. repens, Gwenda, was compared with subterranean clover, Trifolium subterraneum L. (Fabaceae), and strawberry clover, Trifolium fragiferum L. (Fabaceae). These species of clover were chosen because they have a root system that is morphologically similar to $T$. repens (i.e. fibrous and not tap-rooted). Perennial ryegrass, Lolium perenne L. (Poaceae) cv. Parcour, which is commonly sown in mixed swards was also used in this study. Propagation and experiments were conducted in glasshouses $\left(25^{\circ} \mathrm{C} \pm 5^{\circ} \mathrm{C}\right)$, supplemented with artificial light (16:8, light:dark). The plants were grown in John Innes No. 2 compost, and supplied with an Arnon's solution (Hewitt, 1966) modified so that the nitrogen component $\left(\mathrm{NH}_{4} \mathrm{NO}_{3}\right)$ could be manipulated whilst maintaining the balance of the other nutrients (Murray \& Hatch, 1994). Iron was supplied as FeNaEDTA and cobalt was added to encourage nodulation. The solution supplied to L. perenne contained a source of nitrogen $\left(\mathrm{N}^{+\mathrm{ve}}\right.$ solution), whereas that supplied to the clover plants did not ( $\mathrm{N}^{-\mathrm{ve}}$ solution). All plants received $30 \mathrm{ml}$ week $^{-1}$. For all clover species, stolon cuttings with four trifoliate leaves were rooted in the plant compartments of Y-tubes (fig. 1a) and linear tubes (fig. 1b) described in the following section. In the choice tests between L. perenne and T. repens, the same fresh mass was planted in the two arms of the Y-tubes and linear tubes.

\section{Choice tests}

To investigate whether newly hatched S. lepidus larvae could detect the presence of host plant (T. repens) roots and distinguish them from other non-host clover roots and those of a companion grass species, choice tests were conducted at two spatial scales. Firstly, groups of five larvae were introduced $60 \mathrm{~mm}$ from plant roots (macro-scale recognition); and secondly, a single larva introduced $25 \mathrm{~mm}$ from plant roots (meso-scale recognition).

\section{Macro-scale root recognition}

Choice tests were conduced in soil-filled Y-shaped tubes (fig. 1a), analogous to an olfactometer used in choice tests for above-ground insects (McIndoo, 1926), and similar to those described by Boff et al. (2001). The system consisted of a series of circular plastic tubes that were sealed together using waterproof tape. Plants were grown in the terminal sections of the Y-tube arms behind a fine gauze wall that prevented roots growing down the arm (fig. 1a). Tubes were filled with $95 \mathrm{~g}$ of soil (Sonning series B horizon; Jarvis, 1968) that had been dried and sieved (particles $<2 \mathrm{~mm}, 1.24 \mathrm{Mg}$ $\mathrm{m}^{-3}$ dry bulk density), and then watered to give a gravimetric water content of approximately $25 \%$. To ensure a dark soil environment, the Y-tubes were buried in trays of acid washed sand, which were covered with Alcathene ${ }^{\mathrm{TM}}$ 

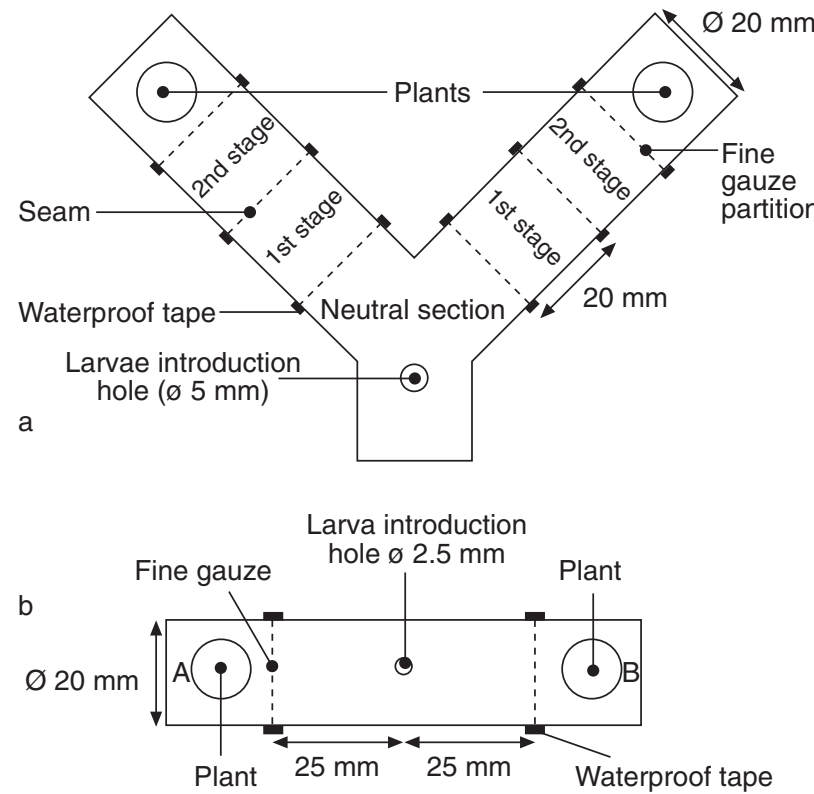

Fig. 1. Schematic of choice tests. (a) Soil filled Y-tube comprising two arms joined at the centre. Plants were grown in terminal ends of each arm behind a fine gauze partition that prevented roots growing into the arms. Five neonatal Sitona lepidus larvae were introduced into a central hole at the base of Y-tube which could be subsequently dismantled into stages. (b) Soil filled linear tubes comprising plants growing in terminal sections behind a fine gauze partition attached to a central horizontal tube. Individual larvae were introduced to the central hole.

granules (diameter $5 \mathrm{~mm}$ ) so that only the aerial parts of the plant were above the surface. Assembled Y-tubes, including the growing plants in the arms, were maintained in a glasshouse for a further 10 days, whereupon five newly hatched larvae were placed inside the larval introduction hole (fig. 1a) that was immediately resealed. Four choice tests, each consisting of 12 Y-tubes, compared: (i) T. repens vs. an arm filled only with soil; (ii) T. repens vs. L. perenne; (iii) $T$. repens vs. T. subterraneum; and (iv) T. repens vs. T. fragiferum. To compensate for any orientational bias by larvae, plants were alternately planted in the left and right arms (six of each). To ensure that nutritional regime (i.e. whether plants received $\mathrm{N}^{+\mathrm{ve}}$ or $\mathrm{N}^{-\mathrm{ve}}$ solution) did not affect larval movement, a further 12 Y-tubes were also assembled, in which the terminal plant sections of both arms contained soil that was treated with $30 \mathrm{ml}$ of either $\mathrm{N}^{+\mathrm{ve}}$ or $\mathrm{N}^{-\mathrm{ve}}$ solution.

Three days after introducing larvae, the Y-tubes were removed from the sand, the sections dismantled, and the soil from each section was immersed in $50 \mathrm{ml} 2 \mathrm{M} \mathrm{Z} \mathrm{ZnCl}_{2}$ (following Sellmer, 1956; Johnson et al., 2004). This forced larvae to the surface and allowed their final location in the Ytubes to be ascertained. To ensure that the quantities of roots in the plant compartments did not affect the result of the choice tests, roots were washed, dried at $80^{\circ} \mathrm{C}$ and weighed.

\section{Meso-scale root recognition}

Four choice tests were conducted in smaller linear tubes (fig. 1b) with a single larva. The plants were grown in terminal ends of the linear tube (fig. 1b) in the same combinations as those growing in the Y-tubes, using 16 replicates of each. The tubes were filled with $34 \mathrm{~g}$ of soil (12 tubes with soil as above, and four with the same soil sieved to $<75 \mu \mathrm{m}$ particles with a dry bulk density of $1.6 \mathrm{Mg} \mathrm{m}^{-3}$ ) and watered to give a gravimetric water content of about 25\%. Assembled tubes were buried horizontally in acid washed sand (as above) for 7 days, whereupon a single $S$. lepidus neonate was placed inside the larval introduction hole (fig. 1b) that was subsequently resealed.

Twelve replicates were destructively sectioned after $12 \mathrm{~h}$, by removing the end of the tube and pushing the soil core out in $1.4 \mathrm{~mm}$ slices from which larvae were recovered by immersion in $10 \mathrm{ml}$ of $2 \mathrm{M} \mathrm{ZnCl}_{2}$. The four tubes containing the soil sieved to $<75 \mu \mathrm{m}$ were examined non-invasively during the $12 \mathrm{~h}$ period using high resolution $\mathrm{X}$-ray microtomography (Johnson et al., 2004). Due to the size constraints of the highresolution X-ray scanner, the two $25 \mathrm{~mm}$ long sections of the linear tube had to be scanned separately. Tubes were scanned at $6 \mathrm{~h}$ intervals; side A (fig. $1 \mathrm{~b}$ ) was scanned at $3 \mathrm{~h}$ and $9 \mathrm{~h}$ and side B (fig. $1 \mathrm{~b}$ ) at $6 \mathrm{~h}$ and $12 \mathrm{~h}$ post larval introduction. Plants were grown on alternate sides of the tube to balance out this discrepancy in scanning time. At the end of the experiment roots were washed, dried at $80^{\circ} \mathrm{C}$ and weighed.

\section{Statistical analysis}

Comparisons of root mass in plant compartments $\left(\log _{10}\right.$ transformations used where data did not conform to normality and homogeneity of variances) were analysed using paired $t$-tests. Choices in Y-tubes and linear tubes were analysed using single sample $\chi^{2}$ tests on insect counts. Progression along Y-tube arms (first or second stages) was analysed using Fisher's exact test of independence (where expected values $<5$ ) (Strike, 1991) or single sample $\chi^{2}$ tests also using insect counts. Larvae remaining in the neutral section (fig. 1a) were omitted from the analysis. Distance burrowed (and burrowing speed) in the linear tubes was analysed using a one-way ANOVA.

\section{Results}

There was no significant difference between the mass of roots in opposing arms of the Y-tubes (fig. 1a) for T. repens and $L$. perenne $\left(\mathrm{t}_{12}=-1.06, P=0.31\right), T$. repens and $T$. subterraneum $\left(\mathrm{t}_{12}=-1.08, P=0.31\right)$ or $T$. repens and $T$. fragiferum $\left(\mathrm{t}_{12}=-1.36, P=0.20\right)$. Similarly, there was no significant difference in root mass planted in linear tubes (fig. 1b) for the same combinations; $\mathrm{t}_{12}=-0.91, P=0.33, \mathrm{t}_{12}=$ $-0.77, P=0.46$ and $t_{12}=-1.01, P=0.34$, respectively. Recovery rates of neonatal larvae from the soil were $100 \%$ in linear tubes and $83 \%$ in the larger Y-tubes.

The distribution of larvae within Y-tubes is shown in fig. 2. Significantly more larvae were recovered from the arm containing T. repens for each combination; T. repens and soil (fig. 2a), T. repens and L. perenne (fig. 2b), T. repens and $T$. subterraneum (fig. 2c) and T. repens and T. fragiferum (fig. $2 \mathrm{~d}$ ). In the test between $\mathrm{N}^{+\mathrm{ve}}$ or $\mathrm{N}^{-\mathrm{ve}}$ solutions with no plants in either arm, larvae showed no significant preference for either arm; $15 \%$ responded to the $\mathrm{N}^{+v e}$ solution and $13 \%$ responded to the $\mathrm{N}^{-\mathrm{ve}}$ solution, with the majority $(72 \%)$ remaining in the neutral section $\left(\chi^{2}{ }_{1 \text { d.f. }}=0.7, P=0.40\right)$.

There was no significant difference in the proportion of larvae progressing to the second stage of either arm for each combination; T. repens and soil (Fisher's exact $P=0.29), T$. repens and L. perenne (Fisher's exact $P=0.99), T$. repens and $T$. 

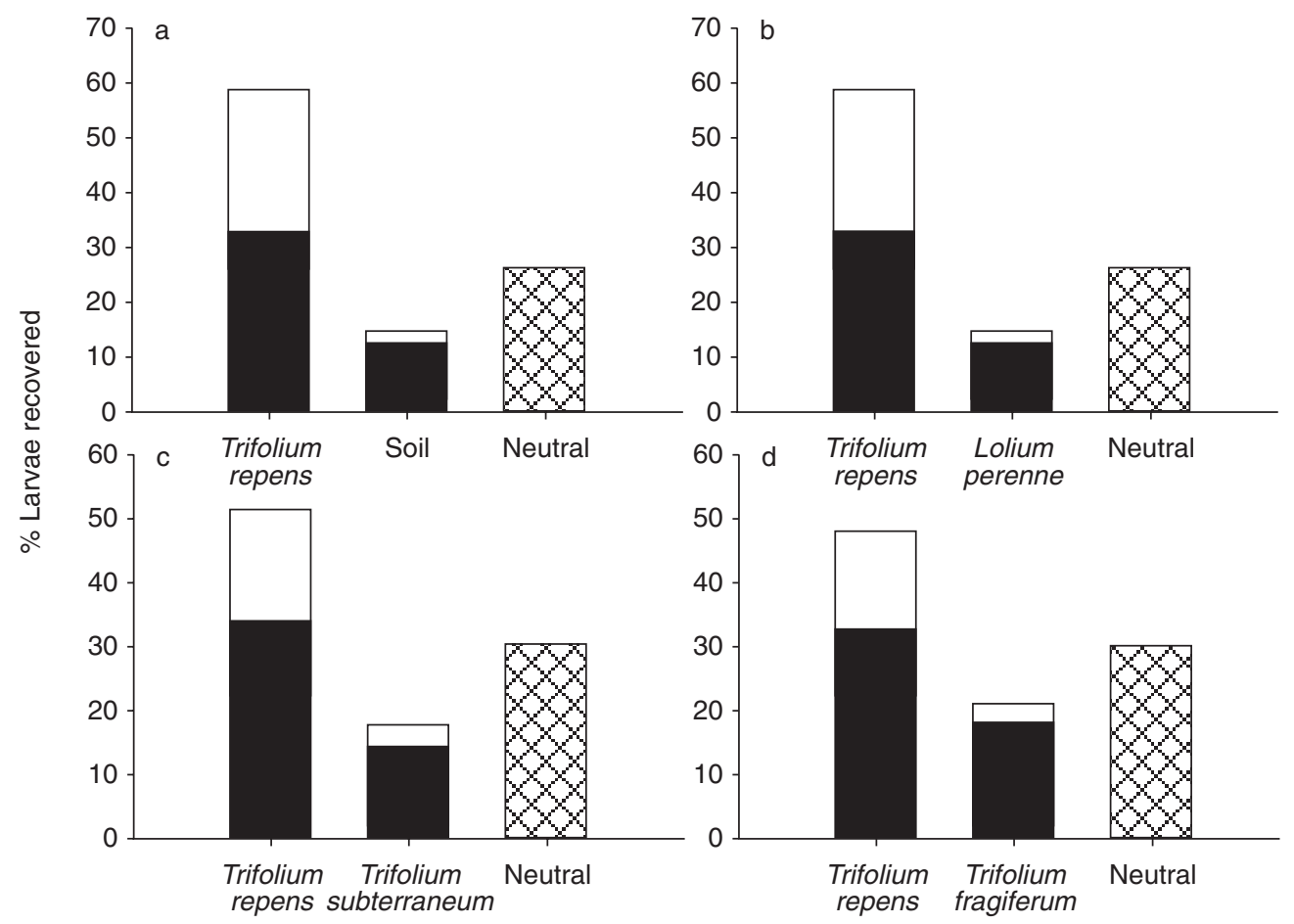

Position of larvae in Y-tube

Fig. 2. Distribution of neonatal Sitona lepidus in Y-tubes (mean \%) after three days, in first stage (closed bars), second stage (open bars) of Y-tube arms (fig. 1a) or remaining in initial neutral section (hatched bar). (a) Trifolium repens vs. a soil-filled arm terminal; $\chi^{2}{ }_{1 \text { d.f. }}=13.44$, $P<0.001$ (b) T. repens vs. Lolium perenne; $\chi^{2}{ }_{1 \text { d.f. }}=12.6, P<0.001$ (c) T. repens in one arm vs. T. subterraneum; $\chi^{2}{ }_{1 \text { d.f. }}=8.26, P<0.01$, and (d) T. repens vs. T. fragiferum; $\chi_{1 \text { d.f. }}^{2}=3.90, P<0.05$.

subterraneum (Fisher's exact $P=0.81$ ) and $T$. repens and $T$. fragiferum (Fisher's exact $P=0.50$ ). There was also no significant difference in larval progress towards $T$. repens roots when different species of plant were grown in the opposing arm $\left(\chi^{2}{ }_{3 \text { d.f. }}=3.76, P=0.29\right)$.

High resolution $X$-ray microtomography successfully located the neonatal S. lepidus larvae in linear tubes (fig. 3). When these results were combined with those from the linear tubes that were destructively sectioned, a similar preference for $T$. repens roots was found as for the Y-tubes. With the exception of $T$. fragiferum, significantly more larvae were recovered from the side of the linear tube that contained T. repens (fig. 4). There was a trend for more larvae to burrow towards $T$. repens roots when grown opposite $T$. fragiferum, but this was not statistically significant in this instance $(P=0.32)$. In summary, the larvae burrowed towards T. repens roots in preference to soil-filled arms and arms containing non-host plant roots when released $25 \mathrm{~mm}$ (meso-scale recognition) and $60 \mathrm{~mm}$ (macro-scale recognition) away from plant roots whether released in groups of five or released singly.

Burrowing distances and rates of movement of larvae towards $T$. repens in the linear tubes did not differ significantly from those burrowing to roots of other plants or soil, although there was a tendency for slower (c. 20\% slower) movement towards $T$. repens (table 1 ). Typically larvae burrowed at about $1.5 \mathrm{~mm} \mathrm{~h}^{-1}$ through the coarser soil of the destructively sectioned tubes and at about $1.0 \mathrm{~mm} \mathrm{~h}^{-1}$ in the denser soil of the tubes used for the X-ray scanning.

\section{Discussion}

This study reports the ability of neonatal S. lepidus larvae to respond to T. repens roots from a distance in the soil, and to distinguish them from roots of companion species such as L. perenne and morphologically similar species of clover. The preference shown by individual larva suggests that this recognition can occur in isolation, although this does not exclude the possibility of larval interaction during host plant location, for instance by pheromone communication.

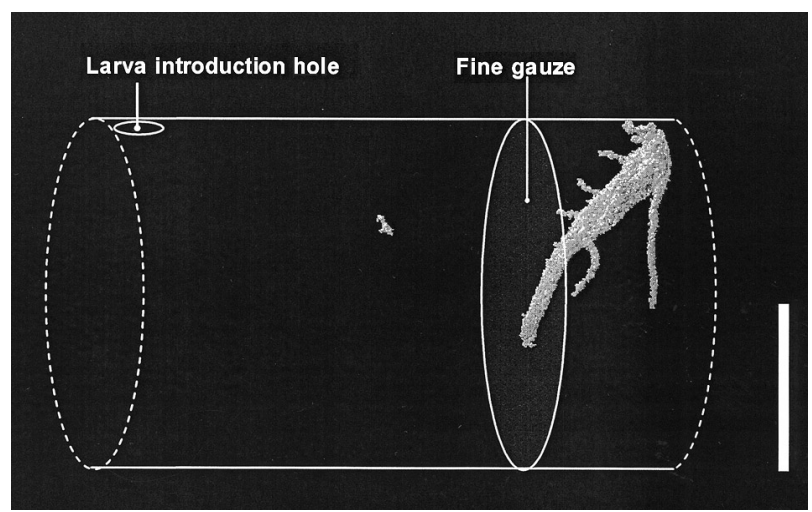

Fig. 3. X-ray tomographic image of neonatal Sitona lepidus larvae burrowing within soil towards the Trifolium repens roots in a section of the linear tube. White bar represents $1 \mathrm{~cm}$. 

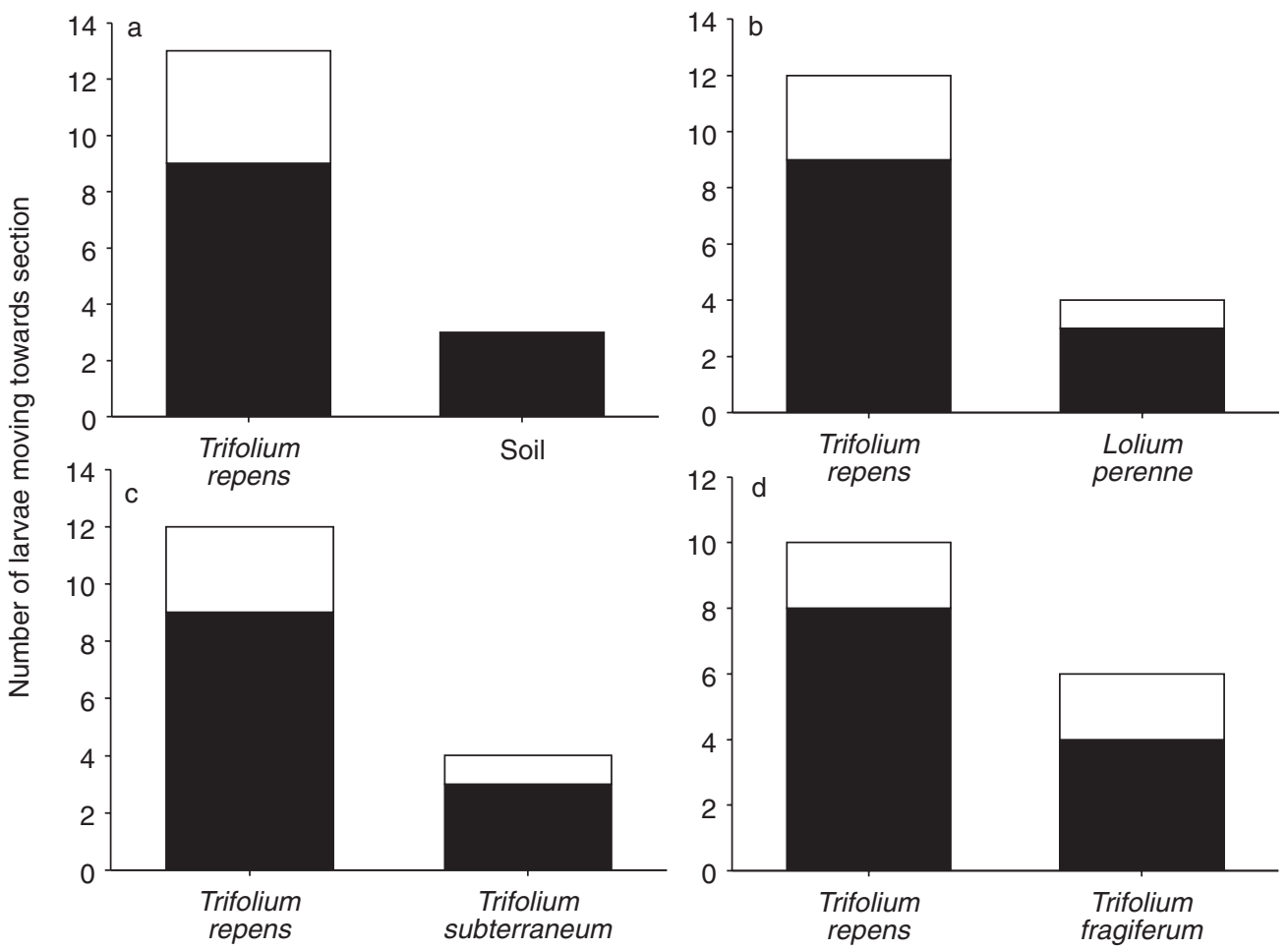

Position of larvae in linear tube

Fig. 4. Direction of burrowing by neonatal Sitona lepidus in linear tubes (number of individuals) after $12 \mathrm{~h}$, as determined by destructively sectioning (closed bars) and X-ray scanned (open bars) linear tubes. (a) Trifolium repens vs. a soil-filled arm terminal; $\chi^{2}{ }_{1}$ df $=6.25, P<0.02$ (b) T. repens vs. Lolium perenne; $\chi^{2}{ }_{1 \text { d.f. }}=4.0, P<0.05$ (c) T. repens in one arm vs. T. subterraneum; $\chi^{2}{ }_{1}$ d.f. $=4.0, P<0.05$, and (d) T. repens vs. $T$. fragiferum; $\chi^{2}{ }_{1 \text { d.f. }}=1.0, P>0.05$.

Table 1. The burrowing distance and speed of neonatal Sitona lepidus larvae towards plant roots in destructively sectioned and X-rayed linear tubes.

\begin{tabular}{|c|c|c|c|c|}
\hline \multirow[t]{2}{*}{ Test combinations } & \multirow[t]{2}{*}{$\begin{array}{l}\text { Direction of larval } \\
\text { movement }\end{array}$} & \multicolumn{2}{|c|}{$\begin{array}{l}\text { Destructively } \\
\text { sectioning tubes }\end{array}$} & \multirow{2}{*}{$\begin{array}{c}\text { X-rayed tubes } \\
\begin{array}{c}\text { Speed }\left(\mathrm{mm} \mathrm{h}^{-1}\right) \\
(\text { mean } \pm 1 \mathrm{SE})\end{array}\end{array}$} \\
\hline & & $\begin{array}{c}\text { Distance travelled } \\
(\mathrm{mm}) \\
(\mathrm{mean} \pm 1 \mathrm{SE})\end{array}$ & $\begin{array}{l}\text { Speed }\left(\mathrm{mm} \mathrm{h}^{-1}\right) \\
(\text { mean } \pm 1 \mathrm{SE})\end{array}$ & \\
\hline \multirow[t]{2}{*}{ T. repens vs. soil } & T. repens & $15.1 \pm 2.14$ & $1.26 \pm 0.18$ & $0.93 \pm 0.21 \dagger$ \\
\hline & Soil & $18.2 \pm 2.42$ & $1.52 \pm 0.20$ & - \\
\hline \multirow[t]{2}{*}{ T. repens vs. L. perenne } & T. repens & $15.2 \pm 2.47$ & $1.27 \pm 0.62$ & $0.86 \pm 0.20$ \\
\hline & L. perenne & $19.6 \pm 5.05$ & $1.63 \pm 0.73$ & $0.57 \pm 0.34$ \\
\hline \multirow[t]{2}{*}{ T. repens vs. T. subterraneum } & T. repens & $15.9 \pm 2.46$ & $1.32 \pm 0.20$ & $1.30 \pm 0.33$ \\
\hline & T. subterraneum & $23.8 \pm 3.52$ & $1.92 \pm 0.29$ & $1.10 \pm 0.35$ \\
\hline \multirow[t]{2}{*}{ T. repens vs. T. fragiferum } & T. repens & $16.6 \pm 2.47$ & $1.39 \pm 0.58$ & $0.86 \pm 0.14$ \\
\hline & T. fragiferum & $15.4 \pm 3.18$ & $1.28 \pm 0.53$ & $1.08 \pm 0.48$ \\
\hline
\end{tabular}

† All larvae burrowed towards T. repens in X-rayed tubes.

Distance and burrowing speed were not significantly different for larvae choosing Trifolium repens rather than soil $\left(\mathrm{F}_{1,10}=0.60, P=0.46\right)$, Lolium perenne $\left(\mathrm{F}_{1,10}=0.72, P=0.42\right)$, T. subterraneum $\left(\mathrm{F}_{1,10}=2.78, P=0.13\right)$ or $\mathrm{T}$. fragiferum $\left(\mathrm{F}_{1,10}=0.09, P=0.76\right)$.

The chemical ecology of insect herbivores that feed on aerial parts of plants is better understood than that of root feeding insects (Bernays \& Chapman, 1994). The results of this study, however, show that host plant location and recognition mechanisms are also present for $S$. lepidus neonates. The few existing studies on host plant location by soil insects have shown that primary metabolites such as respiratory emissions of carbon dioxide can attract soil insects (Bernklau \& Bjostad, 1998a, 1998b), but secondary plant metabolites might also allow soil insects to distinguish between roots of different species (Guerin \& Ryan, 1984; Ross \& Anderson, 1992). The present results suggest that ubiquitous signals such as carbon dioxide are unlikely to be solely responsible for the species-specific discrimination shown by neonatal S. lepidus larvae. The fact that Sitona spp. larvae, of which there are over a hundred species, always 
initially feed on root nodules containing $\mathrm{N}_{2}$-fixing Rhizobium bacteria (Quinn \& Hower, 1986; Wolfson, 1987; Gerard, 2001), raises the possibility that host location and selection might be influenced by these root microbes. Host plant location and selection by above-ground insect herbivores, for instance, frequently involves plant-associated microbes (Barbosa et al., 1991; Bernays \& Chapman, 1994; Johnson et al., 2003).

The slight trend for slower movement of larvae towards T. repens roots was not statistically significant so no conclusions can be drawn about possible orientation mechanisms in the present study, although orientation mechanisms are evident for many other root feeding insects (e.g. Ryan \& Guerin, 1982; Strnad \& Dunn, 1990), so this remains a possibility for $S$. lepidus too.

The period between $S$. lepidus egg-hatch and initial contact with $T$. repens roots is perhaps the least understood part of the life-cycle, and until now it was unclear whether neonatal larvae encountered $T$. repens roots at random whilst burrowing. This study has demonstrated that newly hatched larvae orientate towards $T$. repens roots and are able to distinguish them from roots of other plant species. This study focused on the economically important clover root weevil, but it raises the possibility that host root location by many other subterranean insect herbivores might be equally developed, especially for host-specific species. Unravelling the complexities of host root location by soil dwelling insects has traditionally been hampered by the difficulty associated with studying subterranean insects in the soil in situ (Villani \& Wright, 1990; Hunter, 2001). X-ray microtomography and related techniques open new possibilities for understanding the role of soil properties in regulating insect dispersion and insect-host plant interactions. In particular, the effects of soil packing and particle sizes on larval movement may be important determinants of the amount of time that larvae can survive before locating roots.

\section{Acknowledgements}

The authors would like to thank Denise Headon of the Institute of Grassland and Environmental Research (North Wyke) for collecting insects from the field. This work was financially supported by the BBSRC (project 45/D14536).

\section{References}

Agelopoulos, N., Birkett, M.A., Hick, A.J., Hooper, A.M., Pickett, J.A., Pow, E.M., Smart, L.E., Smiley, D.W.M., Wadhams, L.J. \& Woodcock, C.M. (1999) Exploiting semiochemicals in insect control. Pesticide Science 55, 225-235.

Barbosa, P., Krischik, V.A. \& Jones, C.J. (1991) Microbial mediation of plant-herbivore interactions. New York, John Wiley \& Sons.

Barratt, B.I.P., Barker, G.M. \& Addison, P.J. (1996) Sitona lepidus Gyllenhal (Coleoptera: Curculionidae), a potential clover pest to New Zealand. New Zealand Entomologist 19, 22-30.

Bell, W.J. (1990) Searching behavior patterns in insects. Annual Review of Entomology 35, 447-467.

Bernays, E.A. \& Chapman, R.F. (1994) Host-plant selection by phytophagous insects. New York, Chapman \& Hall.

Bernklau, E.J. \& Bjostad, L.B. (1998a) Behavioral responses of first-instar western corn rootworm (Coleoptera: Chrysomelidae) to carbon dioxide in a glass bead bioassay. Journal of Economic Entomology 91, 444-456.
Bernklau, E.J. \& Bjostad, L.B. (1998b) Reinvestigation of host location by western corn rootworm larvae (Coleoptera: Chrysomelidae): $\mathrm{CO}_{2}$ is the only volatile attractant. Journal of Economic Entomology 91, 1331-1340.

Bigger, J.H. (1930) Notes on the life history of the clover root curculio, Sitona hispidula Fab., in central Illinois. Journal of Economic Entomology 23, 334-342.

Boff, M.I.C., Zoon, F.C. \& Smits, P.H. (2001) Orientation of Heterorhabditis megidis to insect hosts and plant roots in a Ytube sand olfactometer. Entomologia Experimentalis et Applicata 98, 329-337.

Brown, V.K. \& Gange, A.C. (1990) Insect herbivory below ground. Advances in Ecological Research 20, 1-58.

Gerard, P.J. (2001) Dependence of Sitona lepidus (Coleoptera: Curculionidae) larvae on abundance of white clover Rhizobium nodules. Bulletin of Entomological Research 91, 149-152.

Guerin, P.M. \& Ryan, M.F. (1984) Relationship between root volatiles of some carrot cultivars and their resistance to the carrot fly, Psila rosae. Entomologia Experimentalis et Applicata 36, 217-224.

Hewitt, E.J. (1966) Sand and water culture methods used in the study of plant nutrition. Technical Communication of the Commonwealth Agricultural Bureau of Horticultural and Plantation Crops, 22.

Hunter, M.D. (2001) Out of sight, out of mind: the impacts of root-feeding insects in natural and managed systems. Agricultural and Forest Entomology 3, 3-9.

Jarvis, R.A. (1968) Soils of the Reading district. Memoir of the Soil Survey of Great Britain - England $\mathcal{E}$ Wales. Harpenden, Herts, UK.

Johnson, S.N., Douglas, A.E., Woodward, S. \& Hartley, S.E. (2003) Microbial impacts on plant-herbivore interactions: the indirect effects of a birch pathogen on a birch aphid. Oecologia 134, 381-387.

Johnson, S.N., Read, D.B. \& Gregory, P.J. (2004) Tracking larval insect movement within soil using high resolution $\mathrm{X}$-ray microtomography. Ecological Entomology 29, 117-122.

Jones, O.T. \& Coaker, T.H. (1979) Responses of carrot fly larvae, Psila rosae, to the odorous and contact-chemostimulatory metabolites of host and non-host plants. Physiological Entomology 4, 353-360.

McIndoo, N.E. (1926) An insect olfactomter. Journal of Economic Entomology 12, 545-551.

Mowat, D.J. \& Shakeel, M.A. (1989) The effect of different cultivars of clover on numbers of, and leaf damage by, some invertebrate species. Grass and Forage Science 44, $11-18$.

Murray, P.J. \& Clements, R.O. (1994) Investigations of the host feeding preferences of Sitona weevils found commonly on white clover (Trifolium repens) in the UK. Entomologia Experimentalis et Applicata 71, 73-79.

Murray, P.J. \& Hatch, D.J. (1994) Sitona weevils (Coleoptera, Curculionidae) as agents for rapid transfer of nitrogen from white clover (Trifolium repens L) to perennial ryegrass (Lolium perenne L). Annals of Applied Biology 125, 29-33.

Murray, P.J., Hatch, D.J. \& Cliquet, J.B. (1996) Impact of insect root herbivory on the growth and nitrogen and carbon contents of white clover (Trifolium repens) seedlings. Canadian Journal of Botany 74, 1591-1595.

Phillips, C.B., Goldson, S.L., Reimer, L. \& Kuhlmann, U. (2000) Progress in the search for biological control agents of clover root weevil, Sitona lepidus (Coleoptera: Curculionidae). New Zealand Journal of Agricultural Research 43, 541-547. 
Quinn, M.A. \& Hower, A.A. (1986) Effects of root nodules and taproots on survival and abundance of Sitona hispidulus (Coleoptera, Curculionidae) on Medicago sativa. Ecological Entomology 11, 391-400.

Ross, K.T.A. \& Anderson, M. (1992) Larval responses of three vegetable root fly pests of the genus Delia (Diptera: Anthomyiidae) to plant volatiles. Bulletin of Entomological Research 82, 393-398.

Ryan, M.F. \& Guerin, P.M. (1982) Behavioral responses of the carrot fly larva, Psila rosae, to carrot root volatiles. Physiological Entomology 7, 315-324.

Sellmer, G.P. (1956) A method for the separation of small bivalve molluscs from sediments. Ecology 37, 206.

Strike, P.W. (1991) Statistical methods in laboratory medicine. Oxford, Butterworth Heinemann.
Strnad, S.P. \& Dunn, P.E. (1990) Host search behavior of neonate Western corn-rootworm (Diabrotica virgifera virgifera). Journal of Insect Physiology 36, 201-205.

Villani, M.G. \& Wright, R.J. (1990) Environmental influences on soil macroarthropod behavior in agricultural systems. Annual Review of Entomology 35, 249-269.

Wolfson, J.L. (1987) Impact of rhizobium nodules on Sitona hispidulus, the clover root curculio. Entomologia Experimentalis et Applicata 43, 237-243.

(Accepted 25 May 2004)

(C) CAB International, 2004 
